\title{
THE LOST SEAHORSE
}

\author{
by \\ Lizeth Montoya
}

BA, Centro de Estudios Superiores de Diseño de Monterrey, 2011

\begin{abstract}
A major research paper presented to Ryerson University in partial fulfillment of the requirement of the degree of Master of Fine Arts in Documentary Media
\end{abstract}

Toronto, Ontario, Canada, 2019

(C) Lizeth Montoya 2019 


\section{Author's Declaration}

I hereby declare that I am the sole author of this MRP. This is a true copy of the MRP, including any required final revisions. I authorize Ryerson University to lend this MRP to other institutions or individuals for the purpose of scholarly research. I further authorize Ryerson University to reproduce this MRP by photocopying or by other means, in total or in part, at the request of other institutions or individuals for the purpose of scholarly research. I understand that my MRP may be electronically available to the public. 


\begin{abstract}
The Lost Seahorse

Master of Fine Arts, 2019

Lizeth Montoya

Documentary Media

Ryerson University

The Lost Seahorse is a short documentary about my grandmother Irene, who has Alzheimer's disease. The film is a poetic portrait composed of testimonies by her primary caregivers. Recalling memories of Irene, they tackle issues such as absence, loss, and the difficulty of caring for someone you love that has forgotten who you are. Ultimately, the film asks if it is Alzheimer's that ends the identity of a person or if that happens when we forget who they were. This paper exposes the themes that served as a basis for the creation of this project as well as the process of its development.
\end{abstract}




\section{Acknowledgments}

I would like to thank the participants of this film to whom without their help and support this project could not have been done. Thank you to my supervisors Gerda Cammaer and Pierre Tremblay for their guidance and support in following my vision as a filmmaker and to the rest of faculty and peers of the Documentary Media Program for their feedback and encouragement. To my friends back home and in Toronto for being there for me. Thank you as well to Annum Shah and Émeraude Mbuku for their friendship and help at various stages of this project. And to Pearson Ripley for reviewing this paper and helping me navigate the English language throughout the program.

And finally, to my family for their love and invaluable support in the journey of becoming an artist. 
$\underline{\text { Table of Contents }}$

Introduction

1. Memory

1.1 Alzheimer's Disease 3

$\begin{array}{ll}\text { 1.2 Memory Loss and Caregiving } & 9\end{array}$

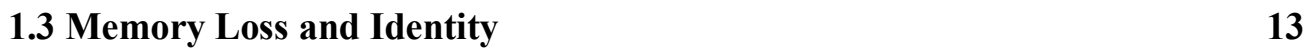

$\begin{array}{lr}1.4 \text { Memory Loss and Place } & 16\end{array}$

2. Methodology

$\begin{array}{lc}\text { 2.1. Home Movies } & 18\end{array}$

2.2 Water as a Metaphor 23

2.3 The Process

$\begin{array}{ll}\text { 2.3.1 Development and Interview Process } & 25\end{array}$

2.3.2 Technical and Ethical Challenges 28

2.3.3 The Use of the Voice 30

$\begin{array}{lll}\text { 2.3.4 The Participants } & 32\end{array}$

3. Documentary Relevance

3.1 Observational and Poetic Modes 36

3.2 Sources of Inspiration 38

$\begin{array}{ll}\text { Conclusion } & 41\end{array}$

Bibliography $\quad 42$ 


\section{Introduction}

My maternal grandmother, Irene, was diagnosed with Alzheimer's disease 19 years ago. She is currently in the seventh stage of Alzheimer's disease, where she is completely dependent on others. ${ }^{1}$ Throughout the years, I have come to understand firsthand what it means to deal with a person that suffers from an illness related to memory loss. Initially, the disease was unknown to my family. Since my mother has served as one of her primary caregivers, it has become a constant in my life. When my family decided to build a home next to my grandparents' property, the concept of memory loss became even closer. This project arose as a means of getting to know the other side of my grandmother and in recognition of her caregivers. At the same time, it emerged out of a need to talk about a very personal topic that has had a significant impact on my family; one that, at times, went unacknowledged.

When I began the interview process for The Lost Seahorse I attempted to not focus entirely on the theme of Alzheimer's due to the emotional weight of the topic. However, this was almost impossible. The illness acts as a veil over my grandmother's true personality, and it has defined her life throughout her later years. Since she cannot remember I had to ask myself: How can one rewrite a memory that has been unwritten? I chose to rewrite it through the memories of others.

Through interviews with people that knew her before and after the onset of the disease, a character portrait is constructed that not only speaks about my grandmother but also questions if a person's identity can be sustained by others. In my opinion, her caregivers function like an orchestra: If one person is lacking or has fallen behind, the entire piece goes out of tune. The nurses, housekeeper, gardener, former chaperones, and her own relatives, are all instruments that sustain her melody. The echo of her personality continues to resonate when we hold onto the recollections, avoiding the possibility of forgetting her and in like manner, being forgotten.

\footnotetext{
${ }^{1}$ Alzheimer's Association, 2016 Alzheimer's Disease Facts and Figures, 17.
} 
My point of departure in constructing this film, was the idea brought forward by Daniel J. Siegel, professor of psychiatry at UCLA School of Medicine and writer, that the mind is not only composed by the perceptions of our experiences but is also made up by those experiences themselves. He argues that "the mind is within us-within the body-and between us." ${ }^{\text {In }}$ order to describe this concept Siegel compares is to the shoreline by saying, "I realized if someone asked me to define the shoreline but insisted, is it the water or the sand, I would have to say the shore is both sand and sea."3 This would imply that Irene's caregivers are not only guardians of the person that she was, but through their experiences and interactions with her, they are also part of her mind.

${ }^{2}$ Daniel J. Siegel, Mind: A Journey to the Heart of Being Human.(NY: W.W. Norton \& Company, 2017), 14, Kindle. ${ }^{3}$ Olivia Goldhill, "Scientists Say Your 'Mind' Isn't Confined to Your Brain, or Even Your Body," Quartz, March 02, 2017, accessed December 18, 2018, https://qz.com/866352/scientists-say-your-mind-isnt-confined-to-your-brain-oreven-your-body/. 


\section{1: Memory}

\subsection{Alzheimer's Disease}

Alois Alzheimer, a German psychiatrist and neuropathologist, is the person credited as identifying the symptoms of an illness that by 1910 was named "Alzheimer's disease." His findings were first published by psychiatrist Emil Kraepelin in his book "Psychiatrie." ${ }^{4}$ According to the Alzheimer's Association, Alzheimer's disease is the most common type of dementia that affects memory, thinking, and behavior. ${ }^{5}$ In North America, the fear of Alzheimer's among men and women over the age of 55 is so severe that anxiety towards it has exceeded that of cancer. ${ }^{6}$ Between the years 2000-2013, deaths attributed to Alzheimer's disease in the United States rose seventy-one percent. ${ }^{7}$ In my home country of Mexico, 800,000 people - or nine percent of the population above sixty - were affected by the disease in the year $2016 .{ }^{8}$ Being the most common type of dementia, a subset of degenerative brain disorders, the terms dementia and Alzheimer's disease are often used interchangeably. ${ }^{9}$ As doctors of medicine Linda C. Lu and Juergen H. Bludau state: “Alzheimer's disease is about more than just losing memory. It is a disease that damages all parts of the brain. It begins by impairing the memory center in the brain, and then progresses to the areas of the brain that control speech, vision, thinking, and reasoning. Overtime, all brain functions are affected." ${ }^{10}$ For this reason, a diagnosis of Alzheimer's disease requires

\footnotetext{
${ }^{4}$ M. Jucker, Alzheimer: 100 Years and Beyond. Berlin, Heidelberg: Springer, 2006, https://ebookcentral-proquestcom.ezproxy.lib.ryerson.ca/lib/ryerson/detail.action?docID=323036\#.

5"Alzheimer's Disease \& Dementia," Alzheimer's Association, accessed April 20, 2018, https://alz.org/alzheimers_disease_what_is_alzheimers.asp.

6 Judes Poirier and Serge Gauthier, Alzheimer's Disease the Complete Introduction (Toronto: Dundurn, 2014), 34.

${ }^{7}$ Alzheimer's Association, 2016 Alzheimer's Disease Facts and Figures.2016, 27.

${ }^{8}$ Laura Toribio, "800 Mil Mexicanos Padecen Alzheimer," Excélsior, September 22, 2016, accessed April 20, 2018, http://www.excelsior.com.mx/nacional/2016/09/22/1118330.

${ }^{9}$ Linda C. Lu and Juergen Bludau, Alzheimer's Disease (Santa Barbara, CA: Greenwood, 2011), 2.

${ }^{10} \mathrm{Lu}$ and Bludau, 3.
} 
symptoms like language impairment or a decline in judgment or decision-making to be present. ${ }^{11}$ Although more than 100 years have passed since Alois Alzheimer first began studying what would eventually be called Alzheimer's disease, no direct cause of the illness has been discovered. ${ }^{12}$ However, risk factors that could lead to the discovery of a cause, have been identified. These risk factors are "something along the line of a gene-environmental combination."13

Nevertheless, there are markers that can signal the risk or presence of the disease in an individual. Those markers are the cerebrospinal fluid (CSF) levels of total Tau (T-Tau), phosphorylated Tau (P-Tau) and beta-amyloid peptide (A $\beta 42) .{ }^{14}$ Beta-amyloid and Tau are the components of plaques and tangles respectively, which eventually cause the malfunction and death of the neurons. ${ }^{15} \mathrm{Lu}$ and Bludau explain: "As the disease progresses, and more and more neurons become injured and die, the affected parts of the brain start to shrink. This process is called brain atrophy and becomes more pronounced in the later stages of the disease. As of right now, no one knows exactly when the disease process starts or what triggers its onset." 16 The disease originates in a part of the brain called the enthorinal cortex, which is next to the hippocampus. ${ }^{17}$ After the neurons start to die the disease spreads to the hippocampus, compromising a crucial part of the brain that plays the role of converting short-term memories into long-term memories. ${ }^{18}$ The

\footnotetext{
${ }^{11}$ Judes Poirer, Serge Gauthier, André Changnon, Michaëlle Jean, and Barbara Sandilands. Alzheimer's Disease: The Complete Introduction (Toronto: Dundurn, 2014), 39.

${ }^{12}$ Linda C. Lu and Juergen Bludau, Alzheimer's Disease (Santa Barbara, CA: Greenwood, 2011), 16.

13 Judes Poirer, Serge Gauthier, André Changnon, Michaëlle Jean, and Barbara Sandilands. Alzheimer's Disease: The Complete Introduction (Toronto: Dundurn, 2014), 82.

14 de Souza, Leonardo Cruz, Marie Sarazin, Antônio Lúcio, Teixeira-Júnior, Paulo Caramelli, Antônio Emanuel dos Santos, and Bruno Dubois. "Biological Markers of Alzheimer's Disease." Arquivos De Neuro-Psiquiatria 72, no.3 (2014):227.

${ }^{15}$ Linda C. Lu and Juergen Bludau, Alzheimer's Disease (Santa Barbara, CA: Greenwood, 2011), 11.

${ }^{16}$ Linda C. Lu and Juergen Bludau, Alzheimer's Disease (Santa Barbara, CA: Greenwood, 2011), 11.

${ }^{17} \mathrm{Lu}$ and Bludau, 11.

18 "Scientists Show Hippocampus's Role In Long Term Memory," ScienceDaily, May 13, 2004, accessed December 21, 2018, https://www.sciencedaily.com/releases/2004/05/040513010413.htm.
} 
processes that occur in the hippocampus help in the creation of autobiographical memory. ${ }^{19}$ The title of my film, The Lost Seahorse, makes reference to the seahorse and to the hippocampus part of the brain, which as mentioned before, is one of the first parts of the brain to be affected by Alzheimer's disease. ${ }^{20}$ It is worth mentioning that the etymology of the hippocampus derives from its resemblance to the seahorse. ${ }^{21}$

There are several categorizations for the stages of the Alzheimer's according to various authors. In this research I decided to follow the Reisberg's Global deterioration scale since it explains the different stages of the disease in a thoroughly manner. ${ }^{22}$

\begin{tabular}{|l|l|}
\hline \multicolumn{2}{|l|}{ Reisberg's Global Deterioration Scale } \\
\hline Stage 1 & No symptoms. \\
\hline Stage 2 & $\begin{array}{l}\text { Mild symptoms (short-term memory lapses, difficulty making decisions) with no } \\
\text { measurable decline on neuropsychological tests. }\end{array}$ \\
\hline Stage 3 & $\begin{array}{l}\text { Mild symptoms with measurable decline on neuropsychological tests, but with no } \\
\text { significant effect on day-to day activities. }\end{array}$ \\
\hline Stage 4 & \begin{tabular}{l} 
Mild dementia (ability to drive a car as long as accompanied by someone). \\
\hline
\end{tabular} \\
\hline
\end{tabular}

${ }^{19}$ Daniel J. Siegel, Mind: A Journey to the Heart of Being Human.(NY: W.W. Norton \& Company, 2017), 169, Kindle.

${ }^{20}$ Aaron Bonner-Jackson. "Alzheimer's and a Shrinking Hippocampus." On Medicine, 15 Oct. 2015, accessed April 20, 2018, https://blogs.biomedcentral.com/on-medicine/2015/10/15/alzheimers-shrinking-hippocampus/

21 “Hippocampus (n.)," Online Etymology Dictionary, accessed August 12, 2019, https://www.etymonline.com/word/hippocampus.

22 Reisberg, Barry. Guide to Alzheimer's Disease (New York, NY: Free Press, 1984), quoted in Judes Poirier, Serge Gauthier, André Changnon, Michaëlle Jean, and Barbara Sandilands. Alzheimer's Disease: The Complete Introduction (Toronto: Dundurn, 2014), 56. 


\begin{tabular}{|l|l|}
\hline Stage 5 & $\begin{array}{l}\text { Moderate dementia (choice of clothing made by someone else; gets around on foot in } \\
\text { familiar places only; finances managed by another person. }\end{array}$ \\
\hline Stage 6 & Severe dementia (must be washed and dressed by another person; cannot be left alone. \\
\hline Stage 7 & Very severe to end-stage dementia (inability to walk safely; difficulty swallowing). \\
\hline
\end{tabular}

The details of these stages were relevant to my research in order to best understand where the health of my grandmother currently lies. In her particular case, the disease progressed slowly over the years. According to this Reisberg's Global Deterioration Scale, she is now in the seventh and final stage of the disease. As she is completely dependent on others for basic activities like grooming, eating, dressing and mobility, I had to be very mindful of her routine in order not to interrupt it abruptly in favor of the filming process. Since she is also not able to consent to being filmed, I had to get permission from her main caregivers as well as her legal guardian. It is also important to mention the matter of ethics in this section. Throughout the process of editing the film, I confronted the dilemma of how much to visually reveal of her current state. My decision was to focus on moments where the caregivers were interacting with her through touch. At the same time, I introduce my grandmother in the film through close-ups that give glimpses of her. I used this technique to show the connection that caregivers have with my grandmother, achieving shots that I felt portrayed her with respect while not avoiding the deterioration of her physical body due to this degenerative illness.

Throughout the stages of the disease, there are particular changes in the emotional and mental state of the person. American writer David Shenk, using the division of early, middle and end stages of the disease, defines several effects that occur during these phases that served as 
inspiration towards the construction of my documentary film. Shenk establishes that during the middle stage, the person repeats "mind-numbing instructions over and over again." 23 There is also what he calls the "confusional stages," where there is often a disorientation of time and place. ${ }^{24}$ This is frequently the period where people will "expect spouses to be young and parents to be alive." ${ }^{25}$ One aspect that I considered to be important to portray in the film was that of the disorientation of time and place. The peak of this is shown in a scene explained by the caregiver, Verónica. In this scene, Verónica describes when my grandmother and her stood in front of the sea but Irene no longer recognized it and even got upset when the ocean wet her feet. I chose this scene because it exemplifies the disorientation as well as the emotional changes that happen to a person as a consequence of Alzheimer's. As the title of my film expresses metaphorically, not only was the specific part of her brain called the hippocampus compromised, but being someone who once liked the sea and was no longer able to recognize it, Irene also lost an orientation with herself. The seahorse got lost in the sea.

The topic of Alzheimer's disease is of great relevance since it is one of the diseases that governments will have to deal with in the near future. Alzheimer's Disease International published in its 2015 annual report that 46.8 million people in the world suffer from dementia and that by 2030, an estimated 74.47 million people will be suffering from the disease. ${ }^{26}$ Such is the concern for the future of the illness that professor of neurology Philip Scheltens et al. stated: "[i]n December 2013, the G8 stated that dementia should be made a global priority and their ambition

\footnotetext{
${ }^{23}$ David Shenk, The Forgetting: Understanding Alzheimer's A Biography of a Disease (London: Harper Collins, 2002), 195 .

${ }^{24}$ Shenk, 196.

${ }^{25}$ Shenk, 196.

${ }^{26}$ Martin Prince et al., "In Summary" In World Alzheimer Report 2015 The Global Impact of Dementia An analysis of prevalence, incidence, cost and trends. (London: Alzheimer's Disease International, 2015),1.
} 
that a cure or a disease-modifying should be available by 2025." 27 As new medicines that prolong life expectancy are discovered and as the global population rises, the challenges brought by the disease will become extensive.

Although some of the facts and figures about Alzheimer's served as inspiration for the film's visual construction and as an influence to develop questions for the interviews, it was never my intention to include them in the film. From the outset, I was pursuing a project that would help me know my grandmother more deeply and serve as an emotional outlet for the people that have dedicated a great deal of time to care for her. Additionally, it was always my intent to transmit emotion to the viewer and make them ponder the concept of memory loss and its direct and indirect effect on people.

${ }^{27}$ Prof. Philip Scheltens et al., “Alzheimer's Disease.” The Lancet, Vol. 388 (2016), 505, doi: 10.1016/S01406736(15)01124-1. 


\subsection{Memory Loss and Caregiving}

The topic of elder caregiving in Mexico is one that lacks substantial research. ${ }^{28}$ Even though there is limited information on the subject, studies show that caregiving in Mexico is mostly done by women. ${ }^{29}$ In the case of my grandmother Irene, the majority of the household duties are done by women with the exception of the gardening, which is performed by a man. During the initial stages of Irene's disease, my mother functioned as the main caregiver. Eventually, as the disease progressed, a woman was hired to accompany my grandmother. Along the way and as Irene lost the ability to take care of her own physical health, other more specialized nurses were hired. Consistent with available data on the subject, in my grandmother's case, it is women who have been her most involved caregivers.

Various terms can be employed in order to define different caregiving roles. Professor Patricia G. Archbold makes the distinction between a care-provider and a care-manager. The former directly performs the duties surrounding the care of the elder while the latter establishes the elder's needs and designates others to provide the care. ${ }^{30}$ As previously mentioned, my mother started as the care provider to my grandmother and as the disease advanced, became the caremanager. Currently, in my grandmother's home there are both care-providers and care-managers. For clarity, the term caregiver will be used in this paper to define a person who cares for an elder, regardless of their distinction as a provider or manager.

\footnotetext{
${ }^{28}$ Carolyn A. Mendez-Luck, David P. Kennedy, and Steven P. Wallace, "Guardians of Health: The Dimensions of Elder Caregiving among Women in a Mexico City Neighborhood," Social Science \& Medicine 68, no. 2 (2009): 233, doi:10.1016/j.socscimed.2008.10.026.

${ }^{29}$ Luis Miguel Gutiérrez Robledo, Mariana López Ortega, and Victoria Eugenia Arango Lopera. "The State of Elder Care in Mexico." Current Geriatrics Reports 1, no. 4 (2012):187, https://doi-org.ezproxy.lib.ryerson.ca/10.1007/s13670-012-0028-z.

${ }^{30}$ Patricia G. Archbold, “Impact of Parent-Caring on Women,” Family Relations 32, no.1 (1983): 41, doi: $10.2307 / 583977$
} 
To be able to comprehend caregiving in Mexico, first the idea of family in the country must be understood. This concept has implications on the decision between caring for the elder within the household or transferring their care to an assisted living facility. As anthropologist Reynaldo Gutiérrez et al. declare: "In Mexico, despite time, social, technological and demographic changes, family continues to be a vital reference, as kinship ties prevail and the members of this institution turn to it for the solution of problems and support." ${ }^{\prime 31}$ It is this strong focus on family and the feeling of responsibility towards the elder, among other things, that leads to the approach that Mexican families (especially women caregivers) have towards caregiving. ${ }^{32}$ In this regard, one of the main differences that exist between developed and developing countries is that "people with dementia in developing countries typically live in large households with extended families." 33 Although my grandmother stayed in her home, about 16 years ago my family decided to build a house next to that of my grandparents in order to facilitate my mother's supervision of my grandmother. The extended family home was, in this instance, formed by two homes that stand next to each other.

In Mexico, care of the elderly mainly occurs at home. ${ }^{34} \mathrm{~A}$ lack of governmental support as well as a feeling of moral obligation often influence a family's decision to care for their loved ones at home. ${ }^{35}$ In the case of my grandmother, all six of her children provide financial support to maintain her health and make her home fully functional. Instead of taking her to a nursing home, they

\footnotetext{
${ }^{31}$ Reynaldo Gutiérrez Capulín, Karen Yamile Díaz Otero, and Rosa Patricia Román Reyes, "El Concepto de Familia En México: Una Revisión desde la Mirada Antropológica y Demográfica," Ciencia Ergo Sum, accessed July 04, 2019, https://www.redalyc.org/jatsRepo/104/10448076002/html/index.html.

32 Carolyn Anne, Méndez. "Informal Caregiving among Women in a Mexico City Suburb: Conceptualizations and Meanings in a Cultural Context." (PhD diss. University of California, 2003), 125, ProQuest Dissertations Publishing.

${ }^{33}$ The 10/66 Dementia Research Group, "Care Arrangements for People with Dementia in Developing Countries," International Journal of Geriatric Psychiatry 19, no.2 (2004): 175, doi:10.1002/gps.1046.

${ }^{34}$ Luis Miguel Gutiérrez Robledo, Mariana López Ortega, and Victoria Eugenia Arango Lopera. "The State of Elder Care in Mexico." Current Geriatrics Reports 1, no. 4 (2012):187, https://doi-org.ezproxy.lib.ryerson.ca/10.1007/s13670-012-0028-z.

35 Carolyn Anne, Méndez. "Informal Caregiving among Women in a Mexico City Suburb: Conceptualizations and Meanings in a Cultural Context." (PhD diss. University of California, 2003), 232, ProQuest Dissertations Publishing.
} 
decided to make modifications to the house and hire personnel according to her needs during the different stages of the disease. My family decided to keep her in her home with the people she is familiar with in order to avoid major changes in her routine that could possibly affect her emotionally. For this reason, the process of caring for her was unique in that many of her caregivers are people that have known her for a long time, even before she had the illness. Caring for my grandmother at her home, provided a way for caregivers to sustain their relationships with her through the different stages of Alzheimer's, whereas in a nursing home, this could have been compromised as a result of employee rotation.

Thanks to the fact that most of Irene's caregivers have been with her for several years-some more than a decade - a bond was established between them. As a result of this bond, there was a creation of what professor María de la Luz Ibarra, calls a "deep alliance" : "Relationships of deep alliance imply that workers commit to stay and care until the end and put their own lives at the service of another for a protracted and undetermined amount of time." ${ }^{36}$ I became very aware of this "deep alliance" during the interview process. Although the caregivers are paid and are still in my grandmother's home because it is their livelihood, they expressed to me several times that they would never leave her when they felt she needed them the most.

Although the relationships between my grandmother and her caregivers were sustained over the years, they underwent many changes as my grandmother's disease progressed. Being a progressive illness that produces behavioral and physical changes in those people that experience it, Alzheimer's constantly demands adaptation from caregivers. ${ }^{37}$ For example, in a specific scene

\footnotetext{
${ }^{36}$ María de La Luz Ibarra, "My Reward Is Not Money. Deep Alliances and End-of-Life Care among Mexicana Workers and Their Wards." In Intimate Labors: Cultures, Technologies, and the Politics of Care, ed. by Eileen Boris and Rhacel Salazar Parreñas ( Stanford, CA: Stanford Social Sciences, 2010), 131-117,https://ebookcentral-proquestcom.ezproxy.lib.ryerson.ca/lib/ryerson/reader.action?docID=683243\&ppg=1.

${ }^{37}$ S. Perren, R. Schmid, and A. Wettstein, "Caregivers' Adaptation to Change: The Impact of Increasing Impairment of Persons Suffering from Dementia on Their Caregivers' Subjective Well-being," Aging \& Mental Health 10, no.5(2006): 539, doi:10.1080/13607860600637844.
} 
with my mother and grandmother, we can observe the shift in roles that occurred in her relationship with Irene when my mother states that she has become my grandmother's mother. It was important for me to display this because it reveals that Irene was no longer the mother able to care for others, but the one that needed to be cared for. 


\subsection{Memory Loss and Identity}

Memory and identity are intertwined concepts for people that are close to dementia since the fear is always present that the memory loss will eventually cause a loss of self. ${ }^{38}$ For this same reason, dementia presents a challenge to caregivers and relatives because the person they might have known before the disease becomes hidden under its veil. With this loss of self, there is also another complex sense of loss experienced by caregivers and relatives since the person they once knew is no longer there even if their body is still present. Psychotherapist Pauline Boss defines this "incomplete or uncertain loss" as "ambiguous loss." 39 Since the body of the person with dementia is still there while their identity has changed or disappeared, there is an ambiguity about the process of loss and grief that cannot be fully completed as is possible in the case of death. Boss names this as the "goodbye without leaving." The Lost Seahorse. It is shown in the emotion with which the caregivers tell stories of my grandmother before the disease, its effects throughout the years, and the devastating reality of her memory loss, most significantly, her inability to recognize the people that surround her. They do, however, continue to remember who she once was. Grief in this case is both a long, wearying process and an emotionally static one.

The central question that arises regarding identity and dementia is whether the individual is still behind that veil or if their identity, in some manner, is being sustained by others. Psychiatrist Carmelo Aquilina and professor of philosophy Julian C. Hughes explain the two poles of this debate in stating that "[a]t one extreme, according to which dementia is understood (purely)

\footnotetext{
${ }^{38}$ Carmelo Aquilina, and Julian C. Hughes. “The Return of the Living Dead: Agency Lost and Found?" in Dementia: Mind, Meaning and Person, ed. Julian C. Hughes et al. (Oxford: Oxford University Press, 2009), 144.

${ }^{39}$ Pauline Boss, Ambiguous Loss: Learning to Live with Unresolved Grief (Cambridge: Harvard University Press, 1999), chap.1. Kindle.

${ }^{40}$ Boss, chap. 3. Kindle.
} 
pathologically, the self disappears irretrievably as the dementia with its pathology worsens. At another extreme, the self can be maintained by the efforts of those around." ${ }^{41}$ The Lost Seahorse presents to the audience this underlying theme of identity loss, in showing how my grandmother has lost a part of herself due to the disease, but, at the same time, how the lost pieces of her identity are preserved by others through their memories and continued interactions with her. Although the film is centered around this question of identity loss, I also make clear through my conceptual choices and creative treatment that I personally believe our identities are partially composed and preserved by those people to which we are closest. In Daniel J. Siegel's book, Mind: A Journey to the Heart of Being Human, I discovered a definition of the psyche that I strongly related to and that eloquently explains the concept of the mind in relation to others. Siegel defines the mind as “...a self-organizing emergent property of energy and information flow happening within you and between you, in your body, and in your connections with others and the world in which you live."42 According to Siegel, the mind is not only the process that occurs within the cerebral structure. It also takes into account our interactions with other individuals; as people relate with one another, they become part of each other's minds. Siegel continues, stating that “...relationships create our mental life, not only influencing it, but also being one of the sources of its very origins, not just what shapes it, but what gives rise to it." ${ }^{23}$ Additionally, the type of relationship and its context within one's life also effects this phenomenon. While making this film, I was curious to uncover the unknown aspects of my grandmother, parts of her that I missed because of my young age at the onset of her memory problems. At the same time, I was also interested in her caregivers and the relation they had to her. As the project progressed, I began to feel that they played a crucial

\footnotetext{
${ }^{41}$ Carmelo Aquilina, and Julian C. Hughes. “The Return of the Living Dead: Agency Lost and Found?" in Dementia: Mind, Meaning and Person, ed. Julian C. Hughes et al. (Oxford: Oxford University Press, 2009), 147.

42 Daniel J. Siegel, Mind: A Journey to the Heart of Being Human. (New York: W.W. Norton Et Company,2017), 50, Kindle

${ }^{43}$ Daniel J. Siegel, Mind: A Journey to the Heart of Being Human. (New York: W.W. Norton Et Company,2017), 10, Kindle
} 
part in my grandmother's life, not only in caring for her health but also as guardians of her memory, maintaining and forming part of those pieces of her mind. It only was when I came across Siegel's concept of the mind, that I found out that this notion is supported by scientific research about the disease.

Although some of Siegel's ideas about the human mind sound questionable, there are others authors that support his view on identity, dementia and the role of others. Psychogerontologist Tom Kitwood mentions how in dementia, the person's past is poured from the inside to the outside to be guarded by others: "In dementia many aspects are again made over to the interpersonal milieu. Memory may have faded, but something of the past is known; identity remains intact, because others hold it in place; thought may have disappeared, but there are still interpersonal processes..." ${ }^{44}$ It is through the relationships the person with dementia has had with individuals that the self is maintained. This occurs due to the various significant relationships such as caregiving, family relations, or both. In The Lost Seahorse I wanted to show the viewer how the people that have surrounded my grandmother can sustain her past identity and simultaneously navigate the different fragments of her identity, as they are gradually dissembled by the disease.

44 Tom Kitwood, Dementia Reconsidered: The Person Comes First (Philadelphia: Open University Press, 1997), 69. 


\subsection{Memory Loss and Place}

Place is a crucial theme in The Lost Seahorse. Irene's house is the physical space where the majority of the film is set. Her house contains the memories of her caregivers but it is also a representation of Irene herself.

The description of this place starts with the exterior, with Lina walking to and arriving at the house. I show the outside of the house in The Lost Seahorse as a way to give the viewer a sense of location but the exterior is of less importance than the interior. It is inside the house that the story of my grandmother is contained. Irene's home, its garden, kitchen and living room, turned out to be silent witnesses of the moments when she once wandered around, interacting with the place itself and with other people. As bodies that inhabited this place moved about, relating with each other, memories were created, or as philosopher Edward S. Casey points out:

To be embodied is ipso facto to assume a particular perspective and position; it is to have not just a point of view but a place in which we are situated. It is to occupy a portion of space from out of which we both undergo given experiences and remember them. To be disembodied is not only to be deprived of place, unplaced; it is to be denied the basic stance on which every experience and its memory depend. ${ }^{45}$

As a result, body, place and memory have an intertwined relationship in which the latter could not exist without the two formers. Although presently there is a rather complicated relationship between my grandmother's body and her home, it is the past memories of her physical movements within it that still linger. It is also the bodies of her family members and caregivers, healthy bodies with sound minds, that continue to inhabit the place, remembering and creating new memories.

Throughout the years, the house has undergone some minor changes. However, the rooms where social interaction used to occur, have been left largely intact, referencing a time when Alzheimer's had not stolen her memories. I filmed the rooms where my family and I used to

${ }^{45}$ Edward S., Casey, Remembering: A Phenomenological Study (Indianapolis: Indiana University Press, 2000), 182, Kindle. 
celebrate Christmas Eve, birthdays or other holidays marked on any family calendar when people usually visit their grandparents; an action emerging from nostalgia. Casey mentions that "Place is selective for memories." ${ }^{\prime 6}$ In other words, those rooms play a major role in recollection due to their accommodation of social interaction: I consider them to be emotionally charged spaces that induce recollections and are of major importance in portraying the effects of the disease. Their present emptiness reflects my grandmother's current mental state. A place once so full of stories, is now an empty vessel due to Alzheimer's.

There are several objects around the house that still bear Irene's mark. In these objects, her identity is still contained. As philosopher and poet Gaston Bachelard mentions, "Being reigns in a sort of earthly paradise of matter, dissolved in the comforts of an adequate matter." ${ }^{47}$ These objects serve as anchors for memories and, at the same time, represent her. To express this particular idea, there is a special emphasis in the film on one specific object in the house: the painting of a lake surrounded by mountains that hangs on the wall above the kitchen table. This is a landscape that was painted by Irene, signed and placed within her house. It serves as an indication of her decorative taste as well as her presence. Or in Bachelard's words: my grandmother is imprinted in this object, hence its central place in the film.

\footnotetext{
${ }^{46}$ Edward S., Casey, Remembering: A Phenomenological Study (Indianapolis: Indiana University Press, 2000), 188, Kindle.

${ }^{47}$ Gaston Bachelard, The Poetics of Space (New York: Penguin Books, 2014), 29.
} 


\section{2: Methodology}

\subsection{Home Movies}

During a trip to my hometown before the summer break, I found several $8 \mathrm{~mm}$ film reels of my family in a drawer at my grandmother's house. Immediately, I realized that I had something exciting in my hands. This was a combination of a longing to find these home movies, and of being intrigued to see what they contained. After finding them I decided to first manually look at all these film reels and meticulously search for moments that seemed interesting to me. This process was important because it gave me a sense of what memories where captured on those reels. After having the archival footage transferred to digital format, I watched all of the films again, this time in order to build a visual archive of shots and scenes that could be used later in the editing stage. This visual archive also made me think about possible scenes that I could film in order to be able to contrast past scenes with present ones. That being said, there were also some moments during the editing process when new images nicely paired up in a coincidental manner with older ones from the $8 \mathrm{~mm}$ reels. There is one specific scene that I very consciously re-constructed based upon what I had found in one of the $8 \mathrm{~mm}$ footage films. This scene is one of the last ones in the film: A baby lays over a blanket followed by a very similar image in the present of another baby in the same position. I purposely constructed that scene to represent the continuity between times along family lines, one showing my grandmother's grandchild and the other, my uncle's grandson. Aside from showing a comparison between times, this specific scene also symbolizes the mental regression that my grandmother went through. I consider that watching the $8 \mathrm{~mm}$ film reels that I found ahead of shooting the film rather than only going over them later in the post-production process, was a great advantage since it allowed me to plan ahead and have more visual resources to work with in the editing stage. 
During the editing process of the film, I decided to use mostly moving images rather than photographs as archival material. There is something in seeing my grandmother's gestures in those moving images which I find tremendously captivating in comparison to the stillness of a photograph; as if movement visually compensated for the limitations she currently has.

Another key aspect of home movies I explore in my film is their fragmentary nature. The way I used them was an attempt to recall former times and to juxtapose the past to the present. Professor Roger Odin in his essay "Le Film de Famille dans L'institution Familiale" (Domestic Cinema in the Familial Institution) explains that home movies are films or videos made by a member of a family about events related to that same family ${ }^{48}$ Contrary to amateur films, which are also made by non-professional filmmakers, home movies can be identified (among other things) as containing non-edited sequences of events with the intention to be screened only in a private setting. ${ }^{49}$ In his book La Casa Abierta. El Cine Doméstico y sus Reciclajes Contemporáneos, professor and film theorist Efrén Cuevas describes that a particular characteristic of home movies is their narrative dispersion and lack of narrative, which makes them "not a text, but just a fragment of a text." 50 Through home movies, I portray moments in the lives of my grandmother and my family that are significant to our history. By using them, I attempt to paint a more complete picture of my grandmother's past self. Moreover, the disjointed and dispersed narrative in the $8 \mathrm{~mm}$ footage served as a form of inspiration in thinking about how memory and its non-linear quality could be reflected in my film. I weave together pieces of

\footnotetext{
${ }^{48}$ Roger Odin, "Le Film de Famille dans L'institution Familiale," in Le Fil de Famille. Usage Privé, Usage Public, ed. Roger Odin (Paris: Meridiens Klincksieck, 1995) 27-41.

${ }^{49}$ Efrén Cuevas, La Casa Abierta: El Cine Doméstico Y Sus Reciclajes Contemporáneos. (Madrid: Ocho y Medio, 2010), 45.

${ }^{50}$ Cuevas, La Casa Abierta, 41.

*Translated from Spanish. "Abierto así por sus dos extremos, el cine doméstico parece destinado a un permanente estado de inconclusión; el cine doméstico no es un texto, es si acaso un fragmente de texto."
} 
information from these home movies in a way that retains their intrinsic fragmentary quality, thus representing how memory and memory loss work.

When inserted into The Lost Seahorse, an interesting contradiction occurs between the home movies and the voice-over narrations that accompany them. Film theorist Rebecca Swender divides the appropriation of archival footage in documentary films into three categories: naturalization, contradiction, and underscoring of conventional specificity. ${ }^{51}$ In his article "Home Movies as Personal Archives in Autobiographical Documentaries," Efrén Cuevas further defines the method of contradiction described by Swender as follows: the process of contradiction can happen when "...[t]he frozen past of those home movies acquire new meanings that were never originally intended when filmed...they become more like ruins of a better past." 52 This is especially exemplified in the scene where it is described that my grandmother did not recognize the sea anymore. Irene appears in the archival footage having fun at the beach and running towards the water as an expression of enjoyment. These images have become ruins of the past, of a better time when my grandmother could take pleasure in the things she liked. Throughout my film, I employ contradiction as a method in order to foreground and emphasize the effects of the disease on Irene. Nostalgia and loss are evidenced in the contradiction between the moments of happiness embedded in these family documents and the voice-over narrations describing things that my grandmother can no longer do.

The use of home movies in The Lost Seahorse is also intended to show a clash in time through a juxtaposition between the past and the present. When memory is lost due to Alzheimer's,

\footnotetext{
${ }^{51}$ Vance Kepley and Rebecca Swender, "Claiming the Found: Archive Footage and Documentary Practice," The Velvet Light Trap 64, no.1 (2009): 6, doi:10.1353/vlt.0.0037.

52 Efrén Cuevas, "Home Movies as Personal Archives in Autobiographical Documentaries, " Studies in Documentary Film 7, no.1 (2013): 24, doi:10.1386/sdf.7.1.17_1.
} 
the gap between the past and the present diminishes because there is a transformation in time. An alteration occurs, past and present seem to be one and the same. This is best exemplified in the vignette of the gardener. He appears in the scene cutting the bougainvillea followed by an image of Irene caring for her plants in a similar manner. This particular instance in the film not only foregrounds the fact that the caregiver has taken over some duties previously performed by Irene, but also highlights this clash between past and present time. Another sequence in the same vignette also portrays a similar transformation in time. After a closeup of flowers, Arturo appears hanging from a tree in an image that has the same format as the previous $8 \mathrm{~mm}$ footage. Here, an interplay between a situation from a former time and an actual one exists. The past touches the limits of the present and vice versa.

It is important to mention that while constructing this documentary, including the selection of archival material, I have had a completely subjective position due to the closeness I have to the topic. Cuevas explains that this subjectivity is challenged when home movies are shown publicly: [T] he rite, personal or collective...mutates into something public that escapes the affective referents that blood ties or friendship carry. This may cause a logic of emotional distance but, on the other hand, it is compensated with a greater objectivity in the perception and a pure enjoyment, free of the connections that bind those who are related to the footage. ${ }^{53}$

As Cuevas denotes, this emotional detachment to the images shown on screen, can facilitate a more objective perspective and liberate the viewer from connections that could otherwise limit their reading of the film. As the viewer is not emotionally attached to the events depicted in the home movies within my film, I deliberately included images that might be familiar to them. The use of typical tropes of home movie footage, such as a beach holiday and the opening of gifts under

\footnotetext{
${ }^{53}$ Efrén Cuevas, La Casa Abierta: El Cine Doméstico Y Sus Reciclajes Contemporáneos. (Madrid: Ocho y Medio, 2010), 16.

*Translated from Spanish. "El rito, personal o colectivo, pero aún dentro de la esfera de lo privado, muta en algo público que escapa los referentes afectivos que conllevan los lazos de la sangre o la amistad. Puede que eso ocasione una lógica de minoración emocional, pero, por otro lado, se compensa con una mayor objetividad en la percepción y un disfrute puro, libre de las vinculaciones propias que atan a quienes forman parte de lo que ellos mismos están viendo."
} 
the Christmas tree, are tools that I used to draw the audience into the film. This is done in order to create familiarity rather than the abstraction that I use in other moments. Although those familiar images are not theirs, my intention is to make the film more relatable by showing common family situations. Janna Jones explains that "the more familiar we are with what we see, the more likely we are to see beyond the screen object and back to our own lifeworld." ${ }^{54}$ However, she clarifies that what compensates the lack of insight is the information given in the narration. She declares that "...[when] the images are not necessarily of our own past...we must attend to the narrative more completely than when we watch our home movies or other films that portray pasts personally familiar to us." ${ }^{55}$ By including the stories of the people related to my grandmother, I affix and connect the viewer to the archival material. Although the images are not explained in a didactic way, the stories narrated serve as a "familiar" context from which to view and understand the visual material.

\footnotetext{
54 Janna Jones, "Confronting the Past in the Archival Film and the Contemporary Documentary." The Moving Image 4, no. 2 (2004): 8.

55 Jones Janna, "Confronting the Past", 8.
} 


\subsection{Water as a Metaphor}

Throughout The Lost Seahorse metaphor is used to present concepts relevant to the story of my grandmother. Water is the most widely explored metaphor in the film. According to professor Ana Munteanu, there are different associations that can be given to water when used as a metaphor, especially in poetry. Water, as she describes “... is usually associated with the feminine principle, the maternal principle, the subconscious, the dark side or the obscurity of the feminine psychic powers, and last but not least, with the depths of the human mind." ${ }^{\circ 6}$ In my film, water has different connotations, referring to the maternal, the mind, and the implications of having a neurodegenerative disease.

The first scene where this metaphor appears is in the third vignette, showing the caregiver named Cristina. The introductory shot shows the painting of the lake done by my grandmother which hangs on the wall near the kitchen table. In the background, a news cast can be heard describing damages to Galeana, a city near my hometown, that were caused by abundant rainfall. It is described that even some families were carried away by the force of the current. With this specific scene, I wanted to introduce the metaphor to the viewer in order talk about the way the disease affected my entire family. Here, water symbolizes the disease, whose "current" swept my family away.

The next moment in the film where water is present as a metaphor is perhaps the most powerful example. This occurs in the fourth vignette, when Verónica explains the anecdote about my grandmother not recognizing the sea anymore. It is in this precise moment that the film makes explicit the degenerative effects caused by Alzheimer's. Here the meaning of the film's title is evident. My grandmother, symbolized by the seahorse, did not recognize what was in front of her. The disease is represented here figuratively, as the void created by her memory loss is symbolized

\footnotetext{
${ }^{56}$ Ana Munteanu, “The Feminine Spirit of Water,” Journal of Research in Gender Studies no.4(2) (2014):1101.
} 
by the vastness of the ocean. The seahorse got lost in the sea. My grandmother, in the vastness of her mind.

In her article “The Feminine Spirit of Water, ” Munteanu describes the relationship between water and the maternal and feminine as follows: "Water is maternal due to its warmness, swing and protection, and feminine due to its coldness, sensuality and waviness. The sea is the Mother, the original matrix towards which both the individual and the whole humanity go in order to sink into it and to find essence." 57 This description is exemplified in the scene where Rosario, the daughter, encounters the ocean. Due to the fact that this scene appears after the explanation describing how my grandmother used to love the sea, water in this scene also represents the maternal. The central image at this point is the daughter entering the sea walking in full clothes. This image symbolizes a cathartic act of returning to one's origin, as if she was returning to her mother.

The last scene which presents this metaphor is the vignette of Rolando, the son. While viewing a picture of my grandmother and her six children, the picture disappears when an image of the sea overlaps it and the living room of my grandmother's house appears. Once again, water represents the disease and how it washed away the recollections. It also serves as a symbolization of the non-linear quality of memory which Rolando compares to the oscillation of the tides.

Water as a metaphor in The Lost Seahorse is used to represent different concepts as my grandmother, the disease she has, mind and memory. My intent was to have not only a recurrent motif throughout the film, but, to set an emotional tone and take advantage of metaphor's power to offer a "density of meaning highly experienced." 58

\footnotetext{
57 Ana Munteanu, “The Feminine Spirit of Water,” Journal of Research in Gender Studies no.4(2) (2014):1108.

58 Trevor Whittock, Metaphor and Film (Cambridge: Cambridge University Press, 1990), 68.
} 


\subsection{The Process}

\subsubsection{Development and Interview Process}

This film started from a need to tell the story of what happened to my maternal grandmother and the impact on my family. Since I have roots in photography, I had explored the theme before with a photographic project about objects around her house that spoke about the condition of dementia. However, this project left me with the need to dive deeper into the topic, by exploring places that were more personal to her and that involve other voices, aside from my own. Once I decided to make a film like this, I went through a process of careful consideration as to how deep I should or could dig into her story. Coming from a family where this painful topic is rarely discussed, I knew that in doing this project I would be opening a door not only to my own pain but to that of others too. This was a struggle for me and I doubted for a long time between either looking for another topic for my film, or continue to explore the theme of Alzheimer and memory loss within this documentary. I finally decided to continue the exploration.

Throughout the first year of the master's program I started doing assignments related to the theme of my grandmother losing her memory. These projects became essential as they functioned as a trial and error phase towards the development of The Lost Seahorse. I made a video for the summer class with the idea of writing a small text and doing a voice-over for it. For this particular video I started experimenting combining archival material and voice-over within a poetic approach. I had already travelled to Mexico in April and had shot some images of my grandmother and her caregivers. However, advised by one of my supervisors I decided to dismiss these images since the perspective I used was overexposing my grandmother as vulnerable and helpless. In July 2018 I returned to Mexico, this time prepared with a more focused idea of the variety of shots I needed and how to position myself as the camera person. The filming process of The Lost Seahorse 
was done approximately over two weeks and a half, and during some extra shooting days months later during the winter break.

When thinking about how to approach the story, I knew that it not only had to be personal, but also had to feel personal. This meant that the center of the film was going to be emotion rather than facts. Consequently, I had to carefully consider the style of narration that was going to be used in the film. This was mainly influenced by the central matter underlying the documentary: the fact that my grandmother lost her memories and can't tell her own story anymore. In order to fill this void, to rewrite a memory that has been unwritten, the film is told in the second person as if everyone is trying to help her remember. I consider this type of narration used throughout the documentary to be one of its strongest qualities, since it gives a higher sense of intimacy to the film and draws in the viewer more than when using the third person.

The style of narration used in The Lost Seahorse became a challenge during the interviews. Some of the interviewees, while talking, switched back and forth between second and third person address. With time, reminders, and strategies such as letting them talk to a photo of my grandmother, the interviews got better and better. During the filming, this method worked both in favor of the project and added difficulty to the process. At times, this type of narration became a path towards a more emotional response from the interviewees, and, in others, it presented itself more as a burden. The latter was the case for the paid caregivers. It is important to note that Mexico is a classist society. ${ }^{59}$ Therefore, there is a power imbalance present that constantly impacted these specific caregivers. The hierarchical position between employer and employee as well as a

\footnotetext{
${ }^{59}$ Pedro Rendón, “Cultura Mexicana, Profundamente Racista, Clasista y Sexista: Rector IBERO.” IBERO, September 05,2017, accessed March 07, 2019, http://www.ibero.mx/prensa/cultura-mexicana-profundamente-racista-clasista-ysexista-rector-ibero.
} 
difference in class (with the filmmaker), caused the interviewees to speak less freely. For them it was particularly difficult to speak in the second person.

Another challenge was the fact that during the interviews it was difficult to get information about the negative traits of my grandmother's personality from both the paid caregivers and the caregivers that are relatives. On one hand, this was complicated due to the class difference and power imbalance in my relationship with the paid caregivers, as I am part of the family that employs them. On the other hand, there is a strong cultural barrier as in Mexico it is taboo to speak negatively about an ill person. Therefore, the film is lacking information about Irene's flaws as mother or employer (before the disease). Despite the fact that I received and included some negative facets of Irene's personality, if I would have been able to show more (negative) aspects of her personality, it would be a more balanced portrait. 


\subsubsection{Technical and Ethical Challenges}

During the process of making this short documentary, there were several ethical and technical concerns that restricted my freedom I during filming. One of the issues I constantly faced, which involved both ethical and stylistic choices, was the previously mentioned fact of how much to reveal about the state of my grandmother's health. Although she has a very scheduled routine and things seemed to be occurring predictably, there were times were I either decided not to shoot what was happening or disregarded the images I had filmed. They show clearly the reality of how Irene's body is going through a process of decline due to a neurodegenerative disease. However, my intent was not to concentrate on and portray the unsightly nature of the illness, but to show its progression through the experiences of others and through the juxtaposition of the past and present. I included only some very selective images of her condition which I felt were necessary for the audience to get an idea of her state without overexposing her vulnerability and growing dependence. As mentioned before in this paper, I had permission from her legal guardian in order to film her. Nonetheless, I still had the ethical challenge of how much to show of a person that is incapable of herself giving consent to being filmed. Despite the fact that I am accustomed to seeing my grandmother in this state, I carefully selected the images that I felt respected her dignity, as I was very conscious of the fact that these are meant for an audience that doesn't know her, and that she doesn't know.

The fact that I was a one-person crew, recording sound, managing the camera and directing, was a major technical challenge. This resulted in some sacrifices, especially in terms of audio, as I was unable to accurately record ambient sounds for all the scenes. The choice to work alone was a result of the nature of this particular documentary, that required filming private family moments which I did not feel comfortable exposing to others. This was a difficult decision as I always 
understood the sacrifices it would involve, but for me my family's privacy was my primary concern.

The way I resolved the challenge of missing ambient sound, was during post-production. With the help of a sound designer, some diegetic sounds were cleaned up and made usable as background noises. For the scenes where it was impossible to restore the diegetic audio, I relied on sound effects. A common sound effect that appears in the film is the sound of water. This was also done with the intention of reinforcing the main metaphor present throughout The Lost Seahorse. While I wanted to create a quiet film (both literally and conceptually), where silence in the background is predominant in order to represent absence, the sound of water is prevalent in this documentary as a gentle force that carries the narrative forward. 


\subsubsection{The Use of the Voice}

Voice plays a crucial role in The Lost Seahorse. It delivers information to the audience and attempts to close the gaps in Irene's life as it is remembered. Moreover, since facial expressions synchronized with sound are absent, tonal quality in the voice gives the viewer direct access to the emotion of the person speaking. This access is given as tone precedes discursive speech in the film. As American psychiatrist Smiley Blanton explains, "the language of the tones is the oldest and most universal of all of our means of communication." ${ }^{60}$ During the development of the film, I decided to experiment further with this after receiving comments about how the tone in the voices was impactful to viewers, even when they were watching it without English subtitles. This is clearly demonstrated in my uncle Rolando's vignette. In this part of the film, it is not only the content of his story that makes the scene emotional, but also the tone of his voice. During the film's post-production, I deliberately used editing techniques to construct a narrative that enhanced the emotional tone present during the interview. For example, I left guttural and sniff sounds in the voice-over with the purpose of preserving the intensity of that particular moment. It is through tone and sounds that loss is communicated to the viewer in a more impactful manner.

In The Lost Seahorse voice is also used to take the film to its climax. After my uncle's emotional narration is finished, his voice becomes a whistle. The whistling scene is the most emotional moment as it represents the culmination of the process of grief and loss experienced by my family and caregivers. Here, all feelings and emotions are condensed into this one particular sound. To whistle was the last form of communication that my uncle had with my grandmother as she gradually lost other means of vocal communication like talking or singing. As Irene's speech became impaired, it was through whistling melodies that she and her child could still relate. This

\footnotetext{
${ }^{60}$ Smiley Blanton, “The Voice and the Emotions,” Quarterly Journal of Speech 1, no.2 (1915):154.
} 
scene is also of great importance because it is the moment that exemplifies best how sound and voice impacts the viewer. Voice and sound create affect when listening to a painful personal story and, consequently, by being emotionally impacted by it. ${ }^{61}$ The melody of the whistle and its emotional tonality in the film gives the viewer a moment where sound and its meaning reach their splendor. The whistle scene creates a moment of catharsis for the audience. Here, a simple whistle becomes the sound of loss.

${ }^{61}$ Siobhán Mchugh, "The Affective Power of Sound: Oral History on Radio," The Oral History Review 39, no. 2 (2012): 195, doi:10.1093/ohr/ohs092. 


\subsubsection{The Participants}

During the process of making this documentary film I interviewed several different people, from relatives to caregivers, in and around my grandmother's home. Every person revealed different facts about my grandmother or about the relationship they have with her. Currently, there are ten people working in my grandmother's house. This includes the nurses, housekeepers, a gardener and the women who take care of the administration of the house (former chaperones). I interviewed most of them and wanted to recognize the work of each one. Notwithstanding, I was limited by the film's intended duration and the need for a cohesive story. I knew that I could only include the stories that were the most emotionally impactful. The criteria I used in order to choose the participants was to select those people that had spent the most time working and caring for the well-being of my grandmother. These participants' contribution to the film is described in what follows:

\section{Lina}

Lina (born Abelina) has worked as my grandmother's housekeeper. She is the worker at the house that has been there for the longest time, 29 years. Therefore, she has witnessed the whole process of the disease. Lina's main contribution to the film is her sense of loyalty to Irene despite these difficult years, where it is shown that she still refuses to share the recipes of my grandmother.

\section{Arturo}

Arturo has worked at the house for ten years. He was hired as a driver for my grandmother in order to take her to doctor's appointments and to do her outings accompanied by her caregivers. As the years passed and my grandmother could not go out anymore, other duties were assigned to him. Arturo's vignette shows the effect that Alzheimer's has had on these caregivers, whereby 
they have had to adapt to the different stages and challenges that accompany the disease. His part in the film also demonstrates the complexity of work relationships in a classist society. Even though this job is his livelihood, there are also emotions of care and love towards his employer.

\section{Cristina}

Cristina is the former chaperone of my grandmother. She has worked in her home for 11 years. Cristina brings to the film reflections on memory and loss and hints at the difficulty of finding ways to care for someone when that person refuses to be cared for. Cristina is also the person that cuts Irene's hair. My purpose in showing this particular scene in the film is to introduce Irene in a gentle way to the viewer. By using close up shots in this vignette, I portray her gestures of touch and care and how this differs between paid care givers and relatives.

\section{Verónica}

Verónica was also a former chaperone of my grandmother. Presently, her job has shifted to doing the administration of the house and managing the other caregivers. Since Verónica has worked for my grandmother for 14 years, she has also closely observed the different stages Irene has gone through after being diagnosed. Verónica was also the companion lady to my grandmother when my grandparents still used to travel. She contributes to the film a crucial story, the one about how my grandmother no longer recognizes the sea. This particular story was the central motivation for the development of the metaphor of water in the film.

\section{Rosario}

Rosario, my mother, has closely cared for Irene since she was diagnosed with Alzheimer's. She has been involved in every part of the process regarding my grandmother's declining health. 
Rosario also serves as the care-manager of Irene and she deals with the administration of her home. Her main contribution to the film is her explanation about how the relationship with her mother has changed. She was once the one being cared for, but now, she has become my grandmother's "mother." Through Rosario, the family's dynamic and my grandmother's role in it is introduced in the film. Another crucial contribution of hers is in showing different approaches to the illness among Irene's children, where some can express their emotions more easily than others.

\section{Rolando}

Rolando is Irene's fourth child. As he used to be in charge of my late grandfather's caregivers, he has spent a lot of time in and around Irene's house. Alongside my mother, he is the relative that has put the most effort into my grandmother's care. I decided to include Rolando (as well as Arturo) to show a sensitive side of the men surrounding my grandmother which contradicts the macho image of men in my country. In the beginning of this project, I was leaning towards only including the voices of those caregivers that have built their livelihood taking care of my grandmother and her house. But after feedback that was given to me in class, as well as a personal desire to do so, I decided to include her relatives as well. This was done to explore and honor the different roles, and different sides of Irene's personality, and to show her as a grandmother, mother, and woman. Likewise, I did this to reveal the emotional side of losing her to dementia. A common question that I came across was why I did not include all of my grandmother's six children. I decided only to include my mother and one uncle because of the six children they were the ones that were most present and they functioned as primary caregivers in the different stages of the disease. They were the ones that saw her progression into oblivion on an almost daily basis and the ones who can recount the story from within this context. Rosario, and especially Rolando, bring a greater sense of loss and emotional character to the film. 


\section{Myself}

Acknowledging the fact that I am not a caregiver of my grandmother I struggled with the decision of including myself in this film. However, I decided to do so in a manner that I felt comfortable with, which was through a voice-over narration of a poem I wrote for this project.

Due to its fragmented form, my narration facilitates a smooth introduction and clear conclusion to the film. I was around 15 years old when my grandmother was diagnosed. I now see that my young age at the time prevented me from seeing the full dimension of her illness. Upon becoming an adult, I realized that I did not know her. Through the people that participated in the making of this film, I was able discover parts of her and my family's history that were unknown to me or that I was unaware of. 


\section{3: Documentary Relevance}

\subsection{Observational and Poetic Modes}

The Lost Seahorse is a short film that can be situated between the observational and the poetic documentary. Bill Nichols defines six different types of representational modes. ${ }^{62}$ In the observational mode, the filmmaker has the position of an observer and gives the impression that they do not intervene in the acts that are being portrayed. These supposedly untouched recorded moments give a feeling to the viewer as if life was unfolding before their eyes. As Nichols states: "We look in on life as it is lived. Social actors engage with one another, ignoring the filmmakers...The scenes, tend like fiction, to reveal aspects of character and individuality. We make inferences and come to conclusions on the basis of behavior we observe or overhear."63 Images in my film follow this notion of events portrayed as they occurred. For the most part, the interviewees are shown carrying out their daily activities.

Another characteristic of the observational documentary is that it "eschews voice-over narration and many other traditional techniques in favor of the observation of the pro-filmic event..." ${ }^{64}$ Nevertheless, alongside the images shown, in my film voice-over narration is used with the images in order to reinforce the idea that they are functioning as "thoughts and memories" of the interviewees. During the production of this film, as both camera operator and director (and because of my interactions with the participants), I was a very present figure in the events. I was never a "fly on the wall," as the overused term describes it. Due to these facts, I do not consider The Lost Seahorse to be an observational documentary in the purest sense, but one that overlaps with other of Nichols' documentary modes.

\footnotetext{
${ }^{62}$ Bill Nichols, Introduction to Documentary. (Indiana: Indiana University Press, 2001), 99.

${ }^{63}$ Nichols, Introduction to Documentary, 111.

${ }^{64}$ Carl Plantinga, "What a Documentary Is, After All," The Journal of Aesthetics and Art Criticism 63, no.2 (2005): 109, doi:10.1111/j.0021-8529.2005.00188.x.
} 
Alongside the observational style used, I employ a poetic approach to the documentary. The intertwining of present and past time, the rhythm, and the visual metaphors that complement the narration are some of the creative strategies I applied to construct the poetic tone. Nichols explains: "The poetic mode is particularly adept at opening up the possibility of alternative forms of knowledge to the straightforward transfer of information, the prosecution of a particular argument or point of view or presentation of reasoned propositions about problems in need of solution." ${ }^{65}$ The Lost Seahorse has a poetic approach wherein the construction of a portrait is not straightforwardly made, but rather information about the person and the disease is given through the recollections of others. The effects of Alzheimer's on an individual and the people surrounding them are as important as the glimpses of information about my grandmother through the subjective view of others, and through images and sounds. In my film, by using this poetic approach I try to convey the viewer the experience of losing someone to dementia rather than feed them facts about the disease. Through the use of the resources mentioned above and the indirect manner in which I address issues in the film, I try to reach the viewer emotionally rather than communicate cognitive information.

With elements of both observational and poetic documentary, The Lost Seahorse is a hybrid documentary. Its topic is well known in the documentary genre, however, I approach it more poetically and in a non-linear fashion, differing from documentaries that have a more informational, journalistic or scientific treatment.

${ }^{65}$ Bill Nichols, Introduction to Documentary. (Indiana: Indiana University Press, 2001), 102. 


\subsection{Sources of Inspiration}

The sources of inspiration for this film are works that portray different forms of loss while communicating the information to the viewer by unconventional means. These works and their influence on my film are described in the following paragraphs.

\section{First Cousin Once Removed (2012) by Alan Berliner}

Alan Berliner's film about his relative Edwin Honing, a professor and translator who suffers from Alzheimer's disease, is a documentary with visual strategies that inspired ones used in The Lost Seahorse. First Cousin Once Removed has a tone that differs from other films that document Alzheimer's disease. While discussing Berliner's film, Daniel Grinberg establishes that other projects "have not responded to the challenges of manifesting the disjunctive, disorienting experiences of Alzheimer's by adapting more unexpected experimental sensory techniques. This formal conservatism reductively aestheticizes the disease as unified, linear and explicable even when the testimonies of people with Alzheimer's assert otherwise." 66 The Lost Seahorse, like First Cousin Once Removed, uses a non-traditional visual treatment to show the fragmented quality of memory in general, and the way it is magnified in a mind suffering from Alzheimer's disease.

Honing's life story and journey through Alzheimer's disease is emphasized by the construction and editing of Berliner's film. Its use of archival footage shows Berliner's cousin before being affected by the disease. Juxtaposed with images from the present, it successfully displays the progress of the disease and its effect on mind and body. Interweaving scenes from the past and present through the use of archival footage is a strategy used in The Lost Seahorse. Where the films differ is in the point of view by which the transformation of the subject is experienced.

\footnotetext{
${ }^{66}$ Daniel Grinberg, "Fading in the Frame: The Epistemology and Ethics of Documenting Alzheimer's Bodies." Studies in Documentary Film 10, no. 1 (2016): 73.
} 
In First Cousin Once Removed, the transformation of Honing is seen through the lens of the filmmaker. In the case of The Lost Seahorse, Irene's transformation is viewed through the testimony of the interviewees in combination with the archival material, which serves as an important second resource to access her past and contrast it with the present.

\section{Reminiscences of a Journey to Lithuania (1972) by Jonas Mekas}

Jonas Mekas's film, Reminiscences of a Journey to Lithuania, is one of the works that also functioned as an inspiration for my short documentary. Mekas's works typically revolves around the theme of displacement and Reminiscences of a Journey to Lithuania is no exception. Mekas returns to his village in Lithuania after twenty-five years of living abroad due to forced exile as a result of World War II. His avant-garde film is a type of self-representation that has been labeled as autoethnography. ${ }^{67}$ As Mekas discusses his own life, particularly displacement and its effects, he is speaking about a broader theme that not only concerns his own milieu, but is implicated in what Catherine Russell calls "larger social formations and historical processes." ${ }^{68}$ Mekas mediates the images in Reminiscences of a Journey to Lithuania through the use of text and a poetic voiceover. The idea of loss is very present in Mekas's work and his longing is expressed through a sustained sadness and nostalgia. As Russell declares, "Memoralization and loss are the defining characteristics of Mekas's diary films, and he renders them as features of the medium itself, enhanced by his poetic, melancholy narration." ${ }^{69}$ Mekas's poetic approach to the description of events serves as a major source of inspiration for my narration as a granddaughter in the film. The

\footnotetext{
${ }^{67}$ Catherine Russell, Experimental Ethnography: The Work of Film in the Age of Video (Durham, N.C.:Duke University Press, 1999), 281.

${ }^{68}$ Russell, Experimental Ethnography, 276.

${ }^{69}$ Russell, 282.
} 
idea of loss, as well as the narrow gap between remembering and forgetting, are themes that I used throughout my film.

\section{All Water Has a Perfect Memory (2001) by Natalia Almada}

Natalia Almada's experimental film, All Water Has a Perfect Memory, was another inspiration for this short film. The film is about an accident suffered in her family in which her older sister drowned and died in the family swimming pool. Due to the fact that Almada was still a baby when this accident happened, she creates a description of the event through the voice-over narration by the people that were witnesses. Her mother, father, and brother recall the memories they had of Anna Lynn (Almada's sister), where they were when the accident happened, and the effect it had on their lives. In the voice-over narration, the themes of memory and its loss are deeply embedded. The erasure and unreachability of relevant facts due to the passing of time served as an inspiration for The Lost Seahorse. The drowning in All Water Has a Perfect Memory presents itself as an unknown family event to the filmmaker where she has to rely on her relatives to fill a gap in her memory. In The Lost Seahorse, information is given to my grandmother about her as if it was unknown to her, filling the void left by her loss of memory. Similarly, by doing so and by making this film in the first place, I was also able to gather information about my grandmother and her life that help to fill the void in my memory. Memory is what is at stake in Almada's short experimental film, and it is the basic subtext for The Lost Seahorse. 


\section{$\underline{\text { Conclusion }}$}

The Lost Seahorse arose from a personal need to create a space in which I could talk about my grandmother's disease, and simultaneously acknowledge the people that have worked tirelessly to maintain her health over this long, 19 year progression. A poetic approach to the film was used to discuss this difficult subject in an indirect manner, through juxtaposition and metaphor, with the purpose of transmitting the feeling of losing someone to dementia. Although despair can overshadow the emotions of people affected by Alzheimer's, with this film I hope to show that this can be understood and experienced in a different way. Caregivers play a crucial role not only as a source of love and care, but as the ones sustaining a person with dementia; serving as guardians of their memories and, somehow, becoming part of that lost mind. Although my grandmother has the privilege of being cared for by various people, I believe that any number of caregivers can function as structures of support, holding together the scattered pieces created by this neurodegenerative disease. Ultimately, the greatest loss would not be that of the memory of the person with the illness, an inevitable reality of life, but rather an inability of those who remain to remember who the person with dementia once was.

Word count: 10,795 


\section{Bibliography}

All Water Has a Perfect Memory. Directed by Natalia Almada. Mexico/US: 2001.

Aquilina, Carmelo and Julian C. Hughes. "The Return of the Living Dead: Agency Lost and Found?" in Dementia: Mind, Meaning and Person, edited by Julian C. Hughes et al. 143-161. Oxford: Oxford University Press, 2009.

Archbold, Patricia G. "Impact of Parent-Caring on Women." Family Relations 32, no. 1 (1983): $39-45$.

Bachelard, Gaston. The Poetics of Space. New York: Penguin Books, 2014.

Blanton, Smiley. 1915. "The Voice and the Emotions.” Quarterly Journal of Speech1 (2): 15472.

Bonner-Jackson, Aaron. "Alzheimer's and a Shrinking Hippocampus." Research in Progress Blog. October 15, 2015. Accessed December 18, 2018. https://blogs.biomedcentral.com/onmedicine/2015/10/15/alzheimers-shrinking-hippocampus/.

Boss, Pauline. Ambiguous Loss: Learning to Live with Unresolved Grief. Cambridge: Harvard University Press, 1999. Kindle.

Capulín, Reynaldo Gutiérrez, Karen Yamile Díaz Otero, and Rosa Patricia Román Reyes. "E1 Concepto De Familia En México: Una Revisión Desde La Mirada Antropológica Y Demográfica." Ciencia Ergo Sum. Accessed July 04, 2019.

https://www.redalyc.org/jatsRepo/104/10448076002/html/index.html.

Casey, Edward S. Remembering: A Phenomenological Study. Indianapolis: Indiana University Press, 2000. Kindle.

Cuevas, Efrén. "Home Movies as Personal Archives in Autobiographical Documentaries." Studies in Documentary Film 7, no. 1 (2013): 17-29. doi:10.1386/sdf.7.1.17_1.

Cuevas, Efrén. La Casa Abierta: El Cine Doméstico Y Sus Reciclajes Contemporáneos. Madrid: Ocho y Medio, 2010.

De La Luz Ibarra, María. "My Reward Is Not Money. Deep Alliances and End-of-Life Care among Mexicana Workers and Their Wards." In Intimate Labors: Cultures, Technologies, and the Politics of Care, edited by Eileen Boris and Rhacel Salazar Parreñas 131-117. Stanford, CA: Stanford Social Sciences, 2010. https://ebookcentral-proquestcom.ezproxy.lib.ryerson.ca/lib/ryerson/reader.action?docID=683243\&ppg=1. 
de Souza, Leonardo Cruz, Marie Sarazin, Antônio Lúcio, Teixeira-Júnior, Paulo Caramelli, Antônio Emanuel dos Santos, and Bruno Dubois. "Biological Markers of Alzheimer's Disease." Arquivos De Neuro-Psiquiatria 72, no.3 (2014):227-231.

First Cousin Once Removed. Directed by Alan Berliner. USA, 2013.

Goldhill, Olivia. "Scientists Say Your "mind" Isn't Confined to Your Brain, or Even Your Body." Quartz. March 02, 2017. Accessed December 18, 2018. https://qz.com/866352/scientists-sayyour-mind-isnt-confined-to-your-brain-or-even-your-body/.

Grinberg, Daniel. "Fading in the Frame: The Epistemology and Ethics of Documenting Alzheimer's Bodies." Studies in Documentary Film 10, no. 1 (2016): 71-86.

Gutiérrez Robledo, Luis Miguel, Mariana López Ortega, and Victoria Eugenia Arango Lopera. "The State of Elder Care in Mexico." Current Geriatrics Reports 1, no. 4 (2012): 183-189. https://doi-org.ezproxy.lib.ryerson.ca/10.1007/s13670-012-0028-z

"Hippocampus (n.)." Online Etymology Dictionary. Accessed August 12, 2019. https://www.etymonline.com/word/hippocampus.

Jones, Janna. "Confronting the Past in the Archival Film and the Contemporary Documentary." The Moving Image 4, no. 2 (2004): x-21.

Kepley, Vance and Rebecca Swender. "Claiming the found: Archive Footage and Documentary Practice." The Velvet Light Trap 64, no. 1 (2009): 3-10.

Kitwood, Tom. Dementia Reconsidered: The Person Comes First. Philadelphia: Open University Press, 1997.

Lu, Linda C., and Juergen Bludau. Alzheimer's Disease. Santa Barbara, CA: Greenwood, 2011. Mendez-Luck, Carolyn A., David P. Kennedy, and Steven P. Wallace . "Guardians of Health: The Dimensions of Elder Caregiving among Women in a Mexico City Neighborhood." Social Science \& Medicine 68, no.2 (2009): 228-234.

Mchugh, Siobhán. "The Affective Power of Sound: Oral History on Radio." The Oral History Review39, no. 2 (2012): 187-206. doi:10.1093/ohr/ohs092.

Méndez, Carolyn Anne. "Informal Caregiving among Women in a Mexico City Suburb: Conceptualizations and Meanings in a Cultural Context." PhD diss., University of California, 2003. ProQuest Dissertations Publishing.

Munteanu, Ana. "The Feminine Spirit of Water." Journal of Research in Gender Studies no.4(2) (2014): 1101-109.

New York University. "Scientists Show Hippocampus's Role In Long Term Memory." ScienceDaily. Www.sciencedaily.com/releases/2004/05/040513010413.htm (accessed December 19, 2018). 
Nichols, Bill. Introduction to Documentary ,1st ed. Indiana: Indiana University Press, 2001.

Odin, Roger. "Le film de famille dans l'instutution familiale." In Le Film de Famille. Usage Privé, Usage Public, edited by Roger Odin, 27-41. Paris: Meridiens Klincksieck, 1995.

Perren, S., R. Schmid, and A. Wettstein. "Caregivers' Adaptation to Change: The Impact of Increasing Impairment of Persons Suffering from Dementia on Their Caregivers' Subjective Well-being." Aging \& Mental Health10, no. 5 (2006): $539-48$. doi:10.1080/13607860600637844.

Plantinga, Carl. "What a Documentary Is, After All." The Journal of Aesthetics and Art

Criticism63, no. 2 (2005): 105-17. doi:10.1111/j.0021-8529.2005.00188.x.

Poirier, Judes, Serge Gauthier, André Changnon, Michaëlle Jean, and Barbara Sandilands. Alzheimer's Disease: The Complete Introduction. Toronto: Dundurn, 2014.

Prince, Martin et al., "In Summary" In World Alzheimer Report 2015 The Global Impact of Dementia An analysis of prevalence, incidence, cost and trends. London: Alzheimer's Disease International, 2015.

Reminiscences of a Journey to Lithuania. Directed by Jonas Mekas. UK: 1972.

Rendón, Pedro. "Cultura Mexicana, Profundamente Racista, Clasista Y Sexista: Rector IBERO." IBERO. September 05, 2017. Accessed March 07, 2019. http://www.ibero.mx/prensa/culturamexicana-profundamente-racista-clasista-y-sexista-rector-ibero.

Russell, Catherine. Experimental Ethnography: The Work of Film in the Age of Video. Durham, N.C.: Duke University Press, 1999.

Scheltens, Philip, Prof. et al., “Alzheimer's Disease.” The Lancet, Vol.388 (2016). doi: 10.1016/S0140-6736(15)01124-1.

Shenk, David. The Forgetting. Understanding Alzheimer's: A Biography of a Disease. London: Harper Collins, 2002.

Siegel, Daniel J. Mind: A Journey to the Heart of Being Human. New York: W.W. Norton Et Company, 2017. Kindle.

The 10/66 Dementia Research Group. "Care Arrangements for People with Dementia in Developing Countries." International Journal of Geriatric Psychiatry19, no. 2 (2004): 17077. doi:10.1002/gps.1046.

Whittock, Trevor. Metaphor and Film. Cambridge: Cambridge University Press, 1990. 